\title{
A Risk Assessment Method for Rockburst Based on Geodynamic Environment
}

\author{
Zhijie Zhu (D), ${ }^{1}$ Hongwei Zhang, ${ }^{1}$ Jun Han ${ }^{(D},{ }^{1}$ and Youchang $\mathrm{Lv}^{2,3}$ \\ ${ }^{1}$ Mining School, Liaoning Technical University, Fuxin, China \\ ${ }^{2}$ State Key Laboratory of Coking Coal Exploitation and Comprehensive Utilization, Pingdingshan, China \\ ${ }^{3}$ Institute of Energy \& Chemical Industry, China Pingmei Shenma Group, Pingdingshan, China
}

Correspondence should be addressed to Jun Han; hanj_lntu@163.com

Received 12 December 2017; Revised 20 May 2018; Accepted 12 June 2018; Published 3 July 2018

Academic Editor: Giosuè Boscato

Copyright (C) 2018 Zhijie Zhu et al. This is an open access article distributed under the Creative Commons Attribution License, which permits unrestricted use, distribution, and reproduction in any medium, provided the original work is properly cited.

\begin{abstract}
Rockbursts are the sudden release of accumulated energy in surrounding rock of roadway and stope. Current studies on the rockburst mechanism are primarily focused on underground mining space and mining activities, whereas efforts have rarely been focused on regional geological dynamics. Mining activities in areas of energy accumulation under the influence of regional geological dynamics can easily cause mine dynamic disasters such as rockburst. The paper statistically analysed the relationship between geological dynamic environment factors (mining depth, tectonic stress, vertical crust movement, active faults, and the ratio of hard rock on the roof) and rockbursts in China and determined the relationship between various factors and the risk of rockbursts. Using a fuzzy comprehensive evaluation method and an analytic hierarchy process (AHP), a risk assessment method for rockburst based on the geological dynamic environment was established. This method was applied to assess the rockburst risk for the Tongxin coal mine in China, and it was evaluated as a weak rockburst risk. The result was consistent with the actual situation. The method provides a new concept for the evaluation and prediction of rockburst in new coal mines or new mining levels.
\end{abstract}

\section{Introduction}

A rockburst is severe dynamical damage caused by the instantaneous release of elastic deformation energy and is often accompanied by outbursts of coal rocks and loud noises. The number of mines experiencing rockburst in China increased from 32 to 160 during the period from 1985 to 2014 [1]. With increasing mining depth and intensity, coal mining is suffering from increasingly severe dynamical disasters, such as rockburst, which largely influence mine safety.

An effective assessment of rockbursts is fundamental for the targeted prevention of rockbursts. A large number of research studies have addressed risk assessments of rockbursts in China and abroad. Cai et al. [2] analysed four indicators (dynamic destruction time, burst energy index, elastic energy index, and uniaxial compressive strength) and built a model based on principal component analysis and fuzzy comprehensive evaluation method to assess tendencies for rockbursts. Wen et al. [3] evaluated the risk levels of rockbursts via the ratio of released energy to absorbed energy in a coal rock system. Wang et al. applied the Seismic CT technique and built a risk assessment model for rockbursts along a mining face using the anomaly coefficient and gradient coefficient of the seismic wave velocity as the main factors [4-7]. In microseismic monitoring, risk evaluations and predictions of rockbursts were performed using the rock stress and destruction states of coal rocks obtained via released energy and magnitude during coal mining [8-10]. Wang et al. studied the rock compositions, motion patterns, and stress distributions of an S-shaped strata structure and investigated a prediction method for rockbursts based on the theory of strata spatial structure [11]. Pan et al. analysed the correlations between concentrated static load and rockbursts and built a risk assessment model for rockbursts [12]. Jiang et al. combined the overall stability of a roadway, local stability of the surrounding rocks, and tendency for coal rockbursts and developed a classification and assessment method for rockbursts based on the relationship between stress and the surrounding rocks. This method identified the potential locations for destruction while reflecting the risk levels for 
rockbursts [13]. Sun et al. proposed an elastic energy criterion for rockbursts through a discussion of a computation method for the elastic energy of the surrounding rocks [14]. Pan et al. predicted a mining rockburst disaster using the drill pipe torque method, the drilling cutting temperature method, and the charge-induced technique [15-17]. Cai et al. argued that two necessary conditions for mining rockbursts are rocks with high strain energies and mining areas with high stress environments [18]. They performed a qualitative analysis and an assessment on the tendency of rockbursts within a deep mining area using multiple criteria. Lu analysed frequencyspectrum evolutionary rule of microseismic (MS) signals before and after roof fall and put forward a specific reference for early warning and evaluating coal rock dynamic disasters [19-21].

Current studies on rockbursts are primarily focused on mining areas and mining activities, whereas efforts have rarely been applied to large-scale regional geodynamic effects. Regional geological dynamics can lead to the redistribution of stress and energy in the crust. Mining in the stress and energy concentration areas can easily cause dynamic disasters, such as rockbursts. Rockbursts are a combined result of modern tectonic movements and mining activities [22, 23]. A geodynamic environment refers to the stress and energy environment in which a dynamic disaster can easily occur under the action of geological dynamics (such as gravitational stress, tectonic stress, tectonic movement, etc.). This paper analyses the impact of the geodynamic environment (mining depth, tectonic stress, vertical movement of the crust, active faults, and roof lithology) on rockbursts and establishes an analytical hierarchy process-fuzzy comprehensive evaluation method for the risk assessment of rockbursts. The Tongxin coal mine in China was used for verification. The risk assessment method for rockbursts based on the geodynamic environment can be used to evaluate the rockburst risks for new mines and new mining levels.

\section{The Relation between Regional Crustal Stability and Mining Dynamical Disasters}

2.1. Geodynamics due to Plate Movements. According to plate tectonics theory, the crust consists of large plates. As a result of boundary stresses, the large plates break into giant blocks, which break into smaller blocks. Consequently, the crust eventually becomes a complex of blocks at multiple scales. A mining area falls within a certain block, and the dynamic environment is influenced by plate movements. The huge energies generated during plate movements are transferred via crustal rock media into subplates, blocks, and mining areas. Tectonic activities can redistribute the stress and energy within rock strata, which generates regions with increasing/decreasing stress and accumulating/releasing energy. A mining dynamical disaster can only occur if energy accumulates within the coal rocks and then mining initiates an energy release [25].

2.2. Geodynamic Effects and Mining Dynamical Disasters. Energy accumulated within a tectonic stress field is the foundation for a mining dynamical disaster. Mining-induced stress and tectonic stress fields are the vital triggers for dynamical disasters. New balances are achieved during plate movements via the redistribution of the stresses and energies within the coal and rock masses [26, 27]. Plate movements lead to the following four conditions: (1) regions of decreased stress and released energy, (2) regions in which stress and energy are simply added, (3) regions of increased stress and accumulated energy (with critical state maxima), and (4) regions with energies that exceed the destruction limits for crustal rocks. Under the first condition, mining does not produce dynamical influences and is safe. Under the second condition, certain preventive measures may be applied to ensure safety. Under the third condition, certain preventive measures should be applied during mining to ensure safety. Under the fourth condition, human engineering activities are irrelevant because energy accumulated within the crust will be released via, for example, volcanic eruptions, earthquakes, and tsunamis.

Rockbursts require certain geodynamic environment and are influenced by multiple factors. Large numbers of mining projects have illustrated that even when employing almost the same mining techniques, some mining areas have suffered rockbursts, whereas others have not, which is due to differences in geodynamic environment. Rockbursts will only occur when mining in a certain geodynamic environment.

\section{Influence of Geological Dynamic Environment Factors on Rockburst}

3.1. Mining Depth. Mining depth is a vital factor that determines whether rockbursts occur. With increasing mining depth, the vertical stress and the elastic energy both increase so that the potential for rockbursts also increases [28]. According to the synthetic index method of risk assessment for rockbursts [29], when $h>800$ metres, the hazard index for rockbursts is 3 . When $\mathrm{h}$ is between 600 metres and 800 metres, the hazard index for rockbursts is 2 . When $h$ is between 400 metres and 600 metres, the hazard index for rockbursts is 1 . When $h \leq 400$ metres, the hazard index for rockbursts is 0 , and there is no risk of rockbursts.

According to the above analysis, the results of rockburst tendency based on mining depth are shown in Table 1.

3.2. Tectonic Stress. Energy accumulations within coal rocks are a combined effect of stress and deformation, and therefore, stress conditions are a vital indicator of rockbursts [30, 31]. Tectonic stress is generated from tectonic movements and is normally horizontal stress.

The ratio of maximal horizontal stress to the vertical stress is defined as the lateral pressure ratio $\lambda$ and reflects the tectonic stress level. The tectonic stress is divided into 4 classes by the lateral pressure ratio $\lambda$, that is, a lateral pressure ratio $\lambda$ less than 1.0, greater than or equal to 1.0 and less than 1.3 , greater than or equal to 1.3 and less than 2.0 , or greater than 2.0. Based on depth and the lateral pressure ratio $\lambda$, the statistics data of 67 rockburst mines and 63 nonrockburst mines in China are shown in Table 2. The table shows that

(1) Among the 10 mines with depths of less than 200 $\mathrm{m}$, there is no rockburst mine found in the different lateral pressure ratios. 
TABle 1: Relationship between depth and rockburst risk.

\begin{tabular}{|c|c|c|c|c|}
\hline Depth(h) & $h \leq 400 \mathrm{~m}$ & $400 \mathrm{~m}<h \leq 600 \mathrm{~m}$ & $600 \mathrm{~m}<h \leq 800 \mathrm{~m}$ & $h>800 \mathrm{~m}$ \\
\hline Risk of rockbursts & Negligible & Slight & Moderate & Serious \\
\hline
\end{tabular}

TABLE 2: Statistics data of rockbursts coal mines with different $\lambda$ value.

\begin{tabular}{|c|c|c|c|c|c|c|c|c|}
\hline \multirow[b]{2}{*}{ Depth /m } & \multicolumn{2}{|c|}{$\lambda<1$} & \multicolumn{2}{|c|}{$1.0 \leq \lambda<1.3$} & \multicolumn{2}{|c|}{$1.3 \leq \lambda<2.0$} & \multicolumn{2}{|c|}{$\lambda \geq 2.0$} \\
\hline & $\begin{array}{c}\text { The number } \\
\text { of mines }\end{array}$ & $\begin{array}{c}\text { The number } \\
\text { of rockburst } \\
\text { mines }\end{array}$ & $\begin{array}{c}\text { The number } \\
\text { of mines }\end{array}$ & $\begin{array}{c}\text { The number } \\
\text { of rockburst } \\
\text { mines }\end{array}$ & $\begin{array}{c}\text { The number } \\
\text { of mines }\end{array}$ & $\begin{array}{c}\text { The number } \\
\text { of rockburst } \\
\text { mines }\end{array}$ & $\begin{array}{l}\text { The number } \\
\text { of mines }\end{array}$ & $\begin{array}{c}\text { The number } \\
\text { of rockburst } \\
\text { mines }\end{array}$ \\
\hline $0 \sim 200$ & 0 & 0 & 4 & 0 & 4 & 0 & 2 & 0 \\
\hline $200 \sim 300$ & 2 & 0 & 4 & $\mathbf{0}$ & 9 & 2 & 1 & 1 \\
\hline $300 \sim 400$ & 1 & $\mathbf{0}$ & 5 & $\mathbf{0}$ & 9 & 4 & 0 & $\mathbf{0}$ \\
\hline $400 \sim 500$ & 1 & 1 & 7 & $\mathbf{0}$ & 6 & 3 & 4 & 4 \\
\hline $500 \sim 600$ & 4 & 1 & 5 & 0 & 6 & 6 & 3 & 3 \\
\hline $600 \sim 700$ & 2 & 2 & 3 & 2 & 5 & 3 & 2 & 2 \\
\hline $700 \sim 800$ & 0 & 0 & 4 & 1 & 6 & 6 & 5 & 5 \\
\hline $800 \sim 900$ & 1 & 1 & 2 & $\mathbf{0}$ & 10 & 10 & 0 & 0 \\
\hline $900 \sim 1000$ & 0 & $\mathbf{0}$ & 1 & 1 & 3 & 1 & 0 & 0 \\
\hline$\geq 1000$ & 1 & 1 & 7 & 6 & 1 & 1 & 0 & 0 \\
\hline
\end{tabular}

(2) Among the 31 mines with depths of between $200 \mathrm{~m}$ and $400 \mathrm{~m}$, there are no rockbursts in the 12 mines with the condition $\lambda<1.3$; there are 6 rockburst mines in the 18 mines with the condition $1.3 \leqslant \lambda<2$, and 1 mine with the condition $\lambda \geqslant 2$ is a rockburst mine.

(3) Among the 36 mines with depths of between $400 \mathrm{~m}$ and $600 \mathrm{~m}$, there are 2 rockburst mines in the 5 mines with the condition $\lambda<1$; there are no rockbursts in the 12 mines with the condition $1 \leqslant \lambda<1.3$; 9 out of 12 mines with the condition $1.3 \leqslant \lambda<2$ are rockburst mines; and all 7 mines with the condition $\lambda \geqslant 2$ are rockburst mines.

(4) Among the 27 mines with depths between $600 \mathrm{~m}$ and $800 \mathrm{~m}$, the 2 mines with lateral pressure ratios less than 1 are rockburst mines; there are 3 rockburst mines in the 7 mines with the condition $1 \leqslant \lambda<1.3$; 9 of the 11 mines with the condition $1.3 \leqslant \lambda<2$ are rockburst mines; and all 7 mines with the condition $\lambda \geqslant 2$ are rockburst mines.

(5) Among the 26 mines with depths greater than 800 $\mathrm{m}$, the two mines with a lateral pressure ratio less than 1 are rockburst mines; 7 out of 10 mines with the condition $1 \leqslant \lambda<1.3$ are rockburst mines; there are 12 rockburst mines in the 14 mines with the condition $1.3 \leqslant \lambda<2$; and there is no statistical data of mines with the condition $\lambda \geqslant 2$.

The above analysis shows that, in the shallow ground (at depths of less than $200 \mathrm{~m}$ ), due to both the low gravity and low tectonic stress level, there are no rockburst mines. With the increase of depth $(200 \mathrm{~m}$ to $400 \mathrm{~m})$, the mines with lateral pressure ratios greater than or equal to 1.3 experience rockbursts. As the depth increases to $400 \mathrm{~m} \sim 500 \mathrm{~m}$, the mines with lateral ratio less than 1 become rockburst mines. At the same mining depth, the greater the lateral pressure ratio, the higher the proportion of rockburst mines. Therefore, under the condition that the buried depth is not taken into consideration, the probability of occurrence of rockburst is positively correlated with the pressure ratio, and the relationship between the pressure ratio of the ground stress and the risk of rockburst is shown in Table 3.

3.3. Vertical Crustal Movement. Figure 1 shows the vertical crustal deformation rate distribution in China's continental crust. It can be seen from Figure 1 that the rise is mainly in the south and the subsidence is mainly in the north; the vertical crustal movement is strong in the west and weak in the east [32].

The statistical analysis of the 160 mines with rockbursts in China is shown in Table 4. The statistics show that rockburst mines are mostly located in the crustal-rise regions and relatively violent movement regions, and few mines in the subsidence regions experience rockbursts. According to the statistics of 160 rockburst mines in China, there are 101 rockburst mines in relatively violent movement regions (movement rate $-1 \mathrm{~mm} / \mathrm{a}<\mathrm{x}<1 \mathrm{~mm} / \mathrm{a}$ ), accounting for $63.13 \%$ of the total. There are 43 rockburst mines located in the rising area of crustal movement (movement rate $x \geq 1 \mathrm{~mm} / \mathrm{a}$ ), accounting for $26.87 \%$ of the total. There are 16 rockburst mines located in the subsidence area with a crustal movement rate $\mathrm{x}<-3 \mathrm{~mm} / \mathrm{a}$, accounting for $10 \%$ of the total statistical mines. Therefore, according to the relationship between the number of rockburst mines and vertical crustal movement, the rockburst risk at different vertical crustal movement rates is shown in Table 5.

3.4. Active Fault. Figure 2 shows the distribution of active faults and rockburst coal mines in China's continental crust. The statistical analysis illustrated that $93.8 \%$ of the 160 mining areas with rockbursts in China are close to a large active fault.

The influence of the range of activity of the fault structures can be obtained [33]:

$$
b=K \cdot 10 h
$$




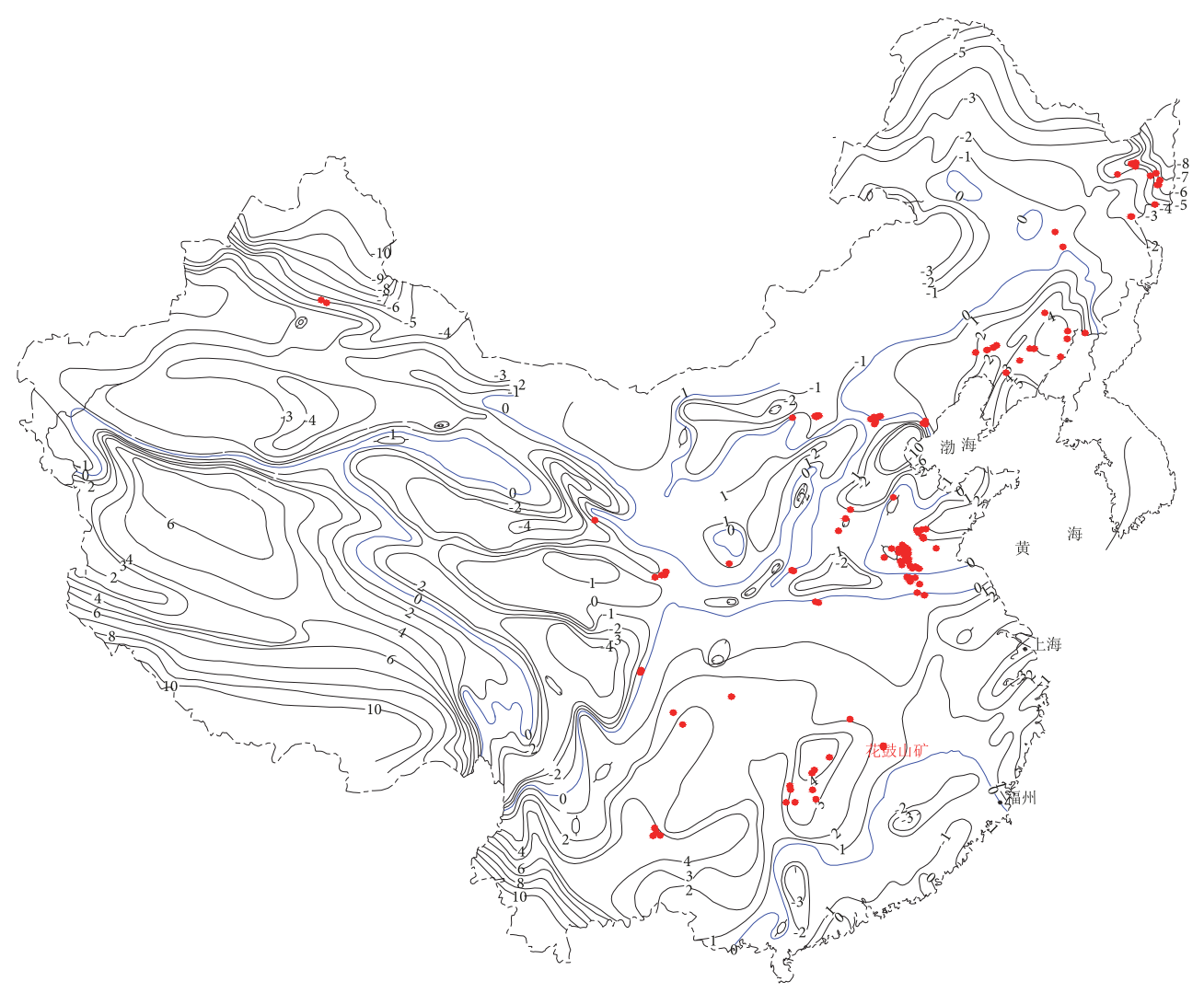

FIGURE 1: Map of vertical crustal deformation rate and rockburst mines in China (circular marks stand for rockburst coal mines).

TABLE 3: Relationship between $\lambda$ value and rockburst risk.

\begin{tabular}{lccc}
\hline $\begin{array}{l}\text { The ratio of maximal horizontal } \\
\text { main stress to the vertical stress } \lambda\end{array}$ & $\lambda<1$ & $1.0 \leq \lambda<1.3$ & $1.3 \leq \lambda<2.0$ \\
\hline Risk of rockbursts & Negligible & Slight & Moderate \\
\hline
\end{tabular}

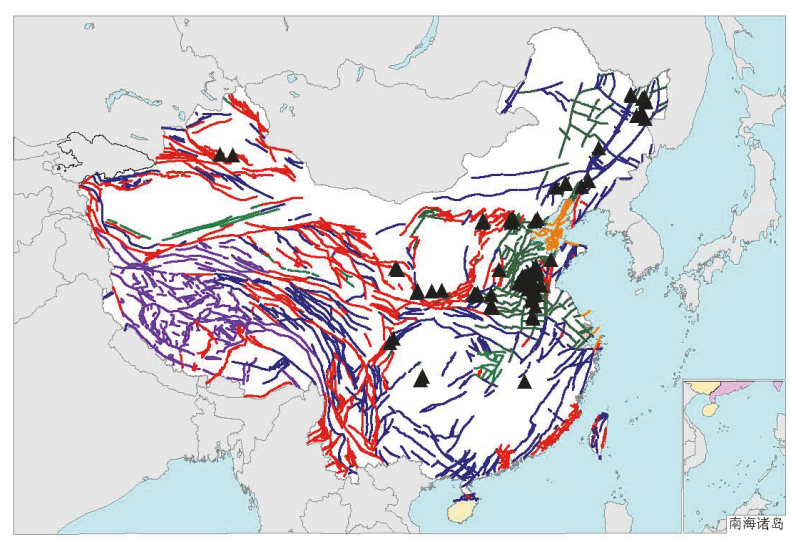

Figure 2: Active faults and rockburst coal mines distribution in China (triangle marks stand for rockburst coal mines).

where $K(=1,2,3)$ is the activity coefficient, and $h$ is the vertical drop of the fault, $m . K=1$ when the fault is weak, $K=2$ when the fault has moderate strength, and $K=3$ when the fault is strong.
According to the Geotechnical Investigation Regulations, breaks in activity occurred after the mid to late Pleistocene, and activity has been strong during the Holocene, with horizontal crustal movement rate $\mathrm{v}>1 \mathrm{~mm} / \mathrm{a}$ and historical earthquake magnitudes $M \geq 7$ being categorized as strong breaks in activity, $0.1 \mathrm{~mm} / \mathrm{a} \leq \mathrm{v} \leq 1 \mathrm{~mm} / \mathrm{a}$ and $5 \leq M<7$ being categorized as medium breaks in activity, and horizontal crustal movement rate $\mathrm{v}<0.1 \mathrm{~mm} / \mathrm{a}$ and historical earthquake magnitudes $M<5$ being categorized as weak breaks in activity.

According to the positional relationship between the rockburst coal mine and the active faults, the rockburst risk in different impact areas of active faults can be determined, as shown in Table 6.

3.5. Ratio of Hard Rock on the Roof. An important inducer of rockbursts is the roof strata condition, including the condition of the hard roof and thick overlying strata. Influenced by the mining conditions, the elastic energy within the thick hard roof is released dramatically and violently, forming a dynamic load that can trigger rockbursts.

Related studies have shown that rock strata within $100 \mathrm{~m}$ above the coal seam have a greater impact on the occurrence 
TABLE 4: Distribution of rockburst coal mines in different crust movement rates.

\begin{tabular}{|c|c|c|c|c|c|c|}
\hline Vertical crustal movement rate $(\mathrm{mm} \cdot \mathrm{a}-1)$ & $-6 \leqq x<-5$ & $-5 \leqq x<-4$ & $-4 \leqq x<-3$ & $-3 \leqq x<-2$ & $-2 \leqq x<-1$ & $-1 \leqq \mathrm{x}<0$ \\
\hline The number of rockburst mines & 7 & 5 & 4 & 0 & 0 & 41 \\
\hline Vertical crustal movement rate $(\mathrm{mm} \cdot \mathrm{a}-1)$ & $0 \leqq x<1$ & $1 \leqq x<2$ & $2 \leqq x<3$ & $3 \leqq x<4$ & $4 \leqq x<5$ & \\
\hline The number of rockburst mines & 60 & 7 & 8 & 10 & 18 & \\
\hline
\end{tabular}

TABLE 5: Relationship between vertical movement rate and rockburst risk.

\begin{tabular}{lllll}
\hline Vertical movement rate $/(\mathrm{mm} \cdot \mathrm{a}-1)$ & $-3 \leqq \mathrm{x} \leqq-1$ & $\mathrm{x}<-3$ & $\mathrm{x} \geq 1$ & $-1<\mathrm{x}<1$ \\
\hline Risk of rockbursts & Negligible & Slight & Moderate & Serious \\
\hline
\end{tabular}

TABLE 6: Risk of rockbursts in different areas of active fractures.

\begin{tabular}{|c|c|c|c|c|}
\hline $\begin{array}{l}\text { Relationship between mine } \\
\text { position and active fault impact } \\
\text { scope b }\end{array}$ & $\mathrm{x}>\mathrm{b}$ & $0.5 \mathrm{~b}<\mathrm{x} \leqq \mathrm{b}$ & $0.3 \mathrm{~b}<\mathrm{x} \leqq 0.5 \mathrm{~b}$ & $\mathrm{X} \leqq 0.3 \mathrm{~b}$ \\
\hline Risk of rockburst & Negligible & Slight & Moderate & Serious \\
\hline
\end{tabular}

TABLE 7: Relationship between the proportion of hard rock and rockburst risk.

\begin{tabular}{lccc}
\hline $\begin{array}{l}\text { The proportion of hard rock } \\
\text { within } 100 \mathrm{~m} \text { of the roof }\end{array}$ & $\mathrm{x}<20 \%$ & $20 \% \leqq \mathrm{x}<50 \%$ & $50 \% \leqq \mathrm{x}<80 \%$ \\
\hline Risk of rockburst & Negligible & Slight & Moderate \\
\hline
\end{tabular}

TABLE 8: The correspondence relationship of rock uniaxial compressive strength $R c$ and rock hardness.

\begin{tabular}{llcccc}
\hline $\boldsymbol{R} \boldsymbol{c}(\mathrm{MPa})$ & $>\mathbf{6 0}$ & $\mathbf{6 0} \sim \mathbf{3 5}$ & $\mathbf{3 0} \sim \mathbf{1 5}$ & $\mathbf{1 5} \mathbf{5}$ & $<\mathbf{5}$ \\
\hline Hardness & Extra Hard Rock & Hard Rock & Slightly Soft Rock & Soft Rock & Extra Soft Rock \\
\hline
\end{tabular}

of rockbursts [34].The statistical analysis of 160 typical mines with rockbursts in China illustrates that as the proportion of hard rock increases, the strength appears to increase. Therefore, the rockburst risk corresponding to the proportion of hard rock above the coal seam was determined, as shown in Table 7.

Hard strata are categorized by the correspondence relationship of rock uniaxial compressive strength and rock hardness (Table 8) according to the Engineering Rock Mass Classification Standards (GB50218-94).

\section{Rockburst Risk Evaluation Based on Fuzzy Comprehensive Evaluation Method and Analytic Hierarchy Process (AHP)}

4.1. Determination of an Evaluation Index System for Rockburst. The first step was to structure an index system and identify the indices. Based on the analysis of the impact of the geodynamic environment on rockburst, five factors, such as mining depth(u1), tectonic stress (u2), vertical crust movement rate (u3), distance between coal mine and active fault ( $\mathrm{u} 4$ ), and the ratio of hard rock in roof (u5), are selected as evaluation indicators. The index system is given as follows:

$$
\mathrm{U}=\{\mathrm{u} 1, \mathrm{u} 2, \mathrm{u} 3, \mathrm{u} 4, \mathrm{u} 5\}
$$

The index system for rockbursts included one layer. The indicators of mining depth and the ratio of hard rock in the roof could be taken from geotechnical boring data. Tectonic stress can be taken from in situ stress measurements. The vertical crust movement rate can be read from Figure 1. The distance between coal mines and active faults can be obtained from the figure of active faults in China's mainland and its neighbouring regions [35].

4.2. Weights of Indices for Rockburst. The weights of the rockburst indices are a constant value in different coal mines. The weights can be obtained using the AHP method. The process is as follows.

4.2.1. Forming Judgement Matrix (A). The relative importance of the indices ( $\mathrm{u} 1, \mathrm{u} 2, \mathrm{u} 3, \mathrm{u} 4$, and $\mathrm{u} 5$ ) with respect to the risk of rockburst can be created according to the experience and knowledge of experts. The relative importance of the two indices to the risk of rockburst can be categorized on a scale ranging from 1 to 9 [36]. A judgement matrix (A) was formed and its structure is given as follows:

$$
A=\left[\begin{array}{ccccc}
1 & 5 & 9 & 7 & 3 \\
\frac{1}{5} & 1 & 5 & 3 & \frac{1}{3} \\
\frac{1}{9} & \frac{1}{5} & 1 & \frac{1}{3} & \frac{1}{7} \\
\frac{1}{7} & \frac{1}{3} & 3 & 1 & \frac{1}{7} \\
\frac{1}{3} & 3 & 7 & 7 & 1
\end{array}\right]
$$


4.2.2. Calculating Weight Vector $(W)$. The maximum eigenvalue $(\lambda \max )$ and the corresponding eigenvector $(X=\{X 1, X 2$, ...Xn, $\}$ ) of the obtained judgement matrix are calculated to satisfy $A X=\lambda X$. The weight vector $(W)$ can be attained by normalizing the eigenvector (X) [37].

The weight vector is

$$
W=(0.4951,0.1305,0.0345,0.0641,0.2759) ;
$$

The maximum eigenvalue is

$$
\lambda_{\text {max }}=5.2849
$$

4.2.3. Consistency Check. The random consistency ratio (CR) is proposed for consistency check.

$$
C R=\frac{C I}{R I}
$$

where $(\mathrm{CI})$ is a consistency indicator, $C I=\left(\lambda_{\max }-\right.$ $n) /(n-1)$ is the average random consistency indicator, and the reference values of (RI) for different numbers of $n$ are shown in Table 9.

When $\mathrm{CR}<0.1$, the judgement matrix can be considered to satisfy the consistency condition; otherwise, the matrix should be adjusted to meet the consistency.

The random consistency ratio is $C R=0.0636$; judgement matrix (A) consistency is acceptable.

The weight vector of rockburst is

$$
W=(0.4951,0.1305,0.0345,0.0641,0.2759)
$$

4.3. Determination of the Evaluation Criteria and Rules. The evaluation criteria of rockburst risk are assumed as negligible, slight, moderate, and serious.

4.4. Determination of the Fuzzy Relationship Matrix. The fuzzy relationship matrix is ascertained as

$$
R=\left[\begin{array}{lllll}
r_{11} & r_{21} & r_{31} & r_{41} & r_{51} \\
r_{12} & r_{22} & r_{32} & r_{42} & r_{52} \\
r_{13} & r_{23} & r_{33} & r_{43} & r_{53} \\
r_{14} & r_{24} & r_{34} & r_{44} & r_{54}
\end{array}\right]^{T}
$$

$\mathrm{R}$ indicates the membership of the $i$ th index belonging to the jth rank.

The membership function is established according to the characteristics of the index system. Trapezoidal membership function and semitrapezoidal membership function models [38] were selected for the indicators of mining depth (u1), tectonic stress (u2), distance between coal mine and active fault ( $\mathrm{u} 4$ ), and the ratio of hard rock in the roof ( $\mathrm{u} 5)$. A rectangular and semirectangular membership function model was selected for the indicator of vertical crust movement rate (u3). Combining the rockburst risk evaluation data of each factor in Tables $1,3,5,6$, and 7 , the corresponding membership functions can be obtained.

(1) Trapezoidal membership function and semitrapezoidal membership function model is as follows:
TABLE 9: The reference values of random consistency indicator.

\begin{tabular}{llcccccccc}
\hline $\mathrm{n}$ & 1 & 2 & 3 & 4 & 5 & 6 & 7 & 8 & 9 \\
\hline $\mathrm{RI}$ & 0 & 0 & 0.58 & 0.90 & 1.12 & 1.24 & 1.32 & 1.41 & 1.45 \\
\hline
\end{tabular}

Class I membership function:

$$
r_{1}(x)= \begin{cases}1 & x<a_{1} \\ \frac{a_{2}-x}{a_{2}-a_{1}} & a_{1} \leq x \leq a_{2} \\ 0 & x>a_{2}\end{cases}
$$

Class II membership function:

$$
r_{2}(x)= \begin{cases}0 & x \leq 2 a_{1}-a_{2} \\ \frac{x-a_{1}}{a_{2}-a_{1}}+1 & 2 a_{1}-a_{2}<x<a_{1} \\ 1 & a_{1} \leq x \leq a_{2} \\ \frac{a_{2}-x}{a_{2}-a_{1}}+1 & x_{1}<x<2 a_{2}-a_{1} \\ 0 & x \geq 2 a_{2}-a_{1}\end{cases}
$$

Class III membership function:

$$
r_{3}(x)= \begin{cases}0 & x \leq 2 a_{2}-a_{3} \\ \frac{x-a_{2}}{a_{3}-a_{2}}+1 & 2 a_{2}-a_{3}<x<a_{2} \\ 1 & a_{2} \leq x \leq a_{3} \\ \frac{a_{3}-x}{a_{3}-a_{2}}+1 & a_{3}<x<2 a_{3}-a_{2} \\ 0 & x \geq 2 a_{3}-a_{2}\end{cases}
$$

Class IV membership function:

$$
r_{4}(x)= \begin{cases}0 & x<a_{2} \\ \frac{x-a_{2}}{a_{3}-a_{2}} & a_{2} \leq x \leq a_{3} \\ 1 & x>a_{3}\end{cases}
$$

(2) Rectangular and semirectangular membership function model is as follows:

Class I membership function:

$$
r_{1}(x)= \begin{cases}1 & x \leq a_{1} \\ 0 & x>a_{1}\end{cases}
$$

Class II membership function:

$$
r_{2}(x)= \begin{cases}1 & a_{1}<x \leq a_{2} \\ 0 & x \leq a_{1} \text { or } x>a_{2}\end{cases}
$$

Class III membership function:

$$
r_{3}(x)= \begin{cases}1 & a_{2}<x \leq a_{3} \\ 0 & x \leq a_{2} \text { or } x>a_{3}\end{cases}
$$


Class IV membership function:

$$
r_{4}(x)= \begin{cases}1 & x>a_{3} \\ 0 & x \leq a_{3}\end{cases}
$$

4.5. Determination of Comprehensive Evaluation Classes of Rockburst Risk. By performing the fuzzy composite operation between the set of fuzzy weights and the fuzzy relationship matrix, a comprehensive evaluation vector is established:

$$
B=W \times R=\left(b_{1}, b_{2}, b_{3}, b_{4}\right)
$$

According to the principle of maximum degree of membership, the corresponding risk level of the largest $b_{\mathrm{j}}(\mathrm{j}=1,2,3$, $4)$ in vector $B$ can be determined.

\section{Verification Case}

5.1. Overview of Engineering Geology in Tongxin Mine. Tongxin coal mine is located in Datong coalfield, Northern China, as shown in Figure 3. No. 3-5 coal seam is mined at an average depth of $450 \mathrm{~m}$, its thickness ranging from 15 to $18 \mathrm{~m}$, dipping between $1^{\circ}$ and $4^{\circ}$. Mechanized cave mining technology was applied to the mining face. The longwall working faces in the Tongxin coal mine are $193 \sim 207 \mathrm{~m}$ wide, 1700 $2000 \mathrm{~m}$ long, and the average seam thicknesses are 16 $\mathrm{m}$. The overlying strata include fine sandstone, coarse grained sandstone, siltstone, medium sandstone, and sandy mudstone (Table 10), among which the sandy rock strata account for 90-95\%. Within 100 metres above the coal seam, there are multiple hard rock strata that are thicker than 10 metres.

The mining depth of coal seam No. 3-5 in the Tongxin mine is $450 \mathrm{~m}$, the maximum horizontal stress is 20.96 $\mathrm{MPa}$, and the vertical stress is $13.8 \mathrm{MPa}$. Thus, the ratio of the maximum horizontal stress to vertical stress is 1.52 . The vertical movement rate of the crust in Tongxin mine is -0.5 $\mathrm{mm} \cdot \mathrm{a}-1$, which is in the relatively violent vertical movement area.

The Kouquan fault zone is to the southeast of the Tongxin coal mine (Figure 4). Its historical seismic level is $6.5(5 \leq \mathrm{M}<7)$. Seismic activity occurred after the mid to late Pleistocene, and severe activity has been observed during the Holocene, indicating that the fault zone remains active. According to the Geotechnical Investigation Regulations, the activity on the Kouquan fault zone is moderate, with $K=2$.

The elevation difference across the Kouquan fault zone is approximately 380 metres, and its width of influence is therefore

$$
b=K \cdot 10 h=2 \times 10 \times 380=7600 \mathrm{~m}
$$

The distance between the edge of the Tongxin coal mine and the Kouquan fault zone is approximately 1200 metres, which is smaller than the serious influence width of $0.3 \mathrm{~b}$ $(7600 \mathrm{~m} \times 0.3=2280 \mathrm{~m})$.

During the mining process, strong strata behaviour occurs, resulting in entry deformation and even damage within a short time frame. It causes roof subsidence (to a maximum

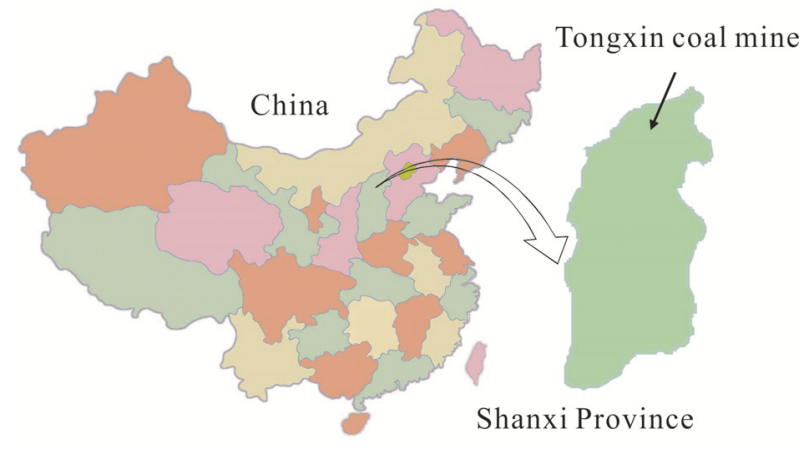

Figure 3: Geographical location of Tongxin coal mine.

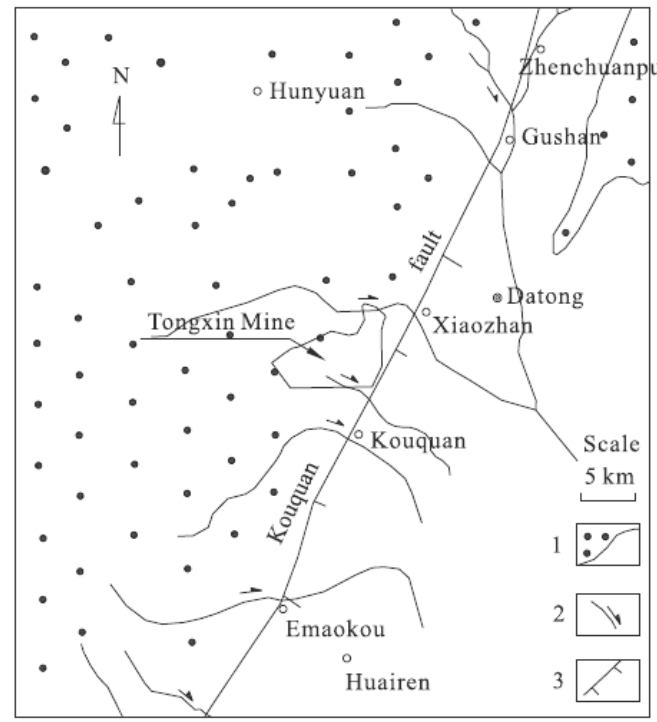

FIGURE 4: Holocene active segment spread of Kouquan fault. [24]. 1 , bedrock mountains and basins; 2 , gullies and flow; 3 , Holocene active range of Kouquan fault.

of $0.5 \mathrm{~m}$ ), floor heave (to a maximum of $1.2 \mathrm{~m}$ ), rib fall, bolt (cable) support failure, and hydraulic prop breakage upon entry, as shown in Figure 5. This result reflected the weak rockburst in the Tongxin coal mine.

5.2. Rockburst Risk Evaluation in Tongxin Mine. According to the above description, the value of each rockburst impact factor can be obtained from Table 11.

The fuzzy relationship matrix $R$ can be obtained by combining the sample data from Table 11 and the membership function of each factor.

$$
R=\left[\begin{array}{ccccc}
0.75 & 0 & 0 & 0 & 0 \\
1 & 0.69 & 0 & 0 & 0 \\
0.25 & 1 & 0 & 0.29 & 0 \\
0 & 0.31 & 1 & 1 & 1
\end{array}\right]^{T}
$$


TABLE 10: Geological data of all the strata overlying above the working face.

\begin{tabular}{|c|c|c|c|c|c|c|c|}
\hline No. & Rock type & Thickness /m & $\begin{array}{l}\text { Compressive } \\
\text { strength } / \mathrm{MPa}\end{array}$ & No. & Rock type & Thickness /m & $\begin{array}{l}\text { Compressive } \\
\text { strength/MPa }\end{array}$ \\
\hline 1 & $\begin{array}{c}\text { No. } 3-5 \text { coal } \\
\text { seam }\end{array}$ & 18.60 & 15.94 & 12 & $\begin{array}{c}\text { Coarse } \\
\text { sandstone }\end{array}$ & 3.90 & 43.87 \\
\hline 2 & $\begin{array}{c}\text { Coarse } \\
\text { sandstone }\end{array}$ & 13.35 & 43.87 & 13 & Siltstone & 4.95 & 55.73 \\
\hline 3 & Siltstone & 7.05 & 55.73 & 14 & Mudstone & 9.60 & 43.23 \\
\hline 4 & $\begin{array}{c}\text { Coarse } \\
\text { sandstone }\end{array}$ & 3.15 & 43.87 & 15 & $\begin{array}{c}\text { Coarse } \\
\text { sandstone }\end{array}$ & 1.80 & 43.87 \\
\hline 5 & Siltstone & 4.35 & 55.73 & 16 & Mudstone & 3.15 & 41.35 \\
\hline 6 & Sandy mudstone & 5.55 & 41.35 & 17 & $\begin{array}{c}\text { Coarse } \\
\text { sandstone }\end{array}$ & 11.85 & 43.87 \\
\hline 7 & Siltstone & 1.95 & 55.73 & 18 & Sandy mudstone & 7.05 & 41.35 \\
\hline 8 & Fine sandstone & 1.65 & 61.53 & 19 & $\begin{array}{l}\text { Coarse } \\
\text { sandstone }\end{array}$ & 2.55 & 43.87 \\
\hline 9 & Siltstone & 2.25 & 55.73 & 20 & Sandy mudstone & 15.60 & 41.35 \\
\hline 10 & $\begin{array}{c}\text { Coarse } \\
\text { sandstone }\end{array}$ & 14.85 & 43.87 & 21 & Siltstone & 3.75 & 55.73 \\
\hline 11 & Siltstone & 4.35 & 55.73 & & & & \\
\hline
\end{tabular}

TABLE 11: The value of each rockburst impact factor in the Tongxin coal mine.

\begin{tabular}{|c|c|c|c|c|c|}
\hline Index & Mining depth /m & $\begin{array}{l}\text { The ratio of maximal } \\
\text { horizontal main stress to } \\
\text { the vertical stress }\end{array}$ & $\begin{array}{c}\text { Vertical crustal } \\
\text { deformation rate ( } \\
\mathrm{mm} \cdot \mathrm{a}-1)\end{array}$ & $\begin{array}{c}\text { Distance between } \\
\text { mine position and } \\
\text { active fault ( } \mathrm{b}=7600 \\
\mathrm{~m})\end{array}$ & $\begin{array}{c}\text { Ratio of hard rock } \\
\text { on the roof }\end{array}$ \\
\hline Value & 450 & 1.52 & -0.5 & 1200 & $100 \%$ \\
\hline
\end{tabular}

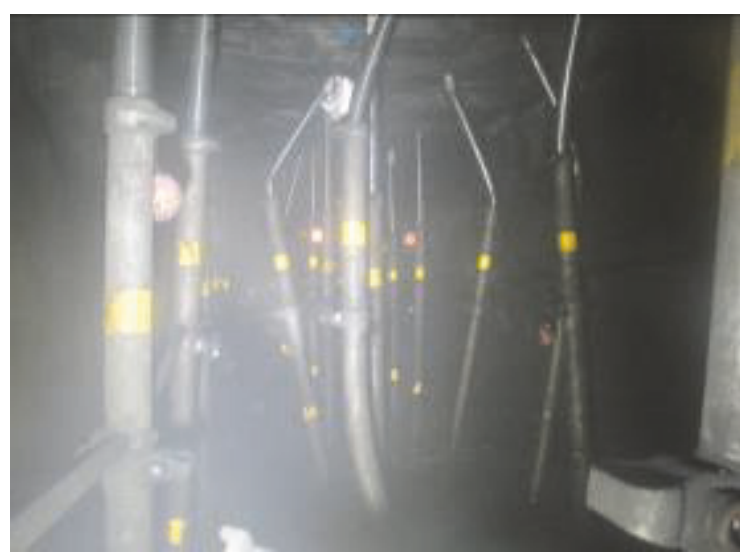

FIGURE 5: Hydraulic prop break in entry [24].

Once the fuzzy relation matrix $R$ and the weight vector $W$ are brought into the fuzzy comprehensive evaluation formula, the judging vector $B$ can be obtained:

$$
B=(0.3713,0.5851,0.2729,0.4150) \text {. }
$$

So the degree of membership of rockburst risk's influence factors can be shown in Table 12 .

According to the principle of maximum subordination, it can be determined that the Tongxin coal mine is a slight rockburst mine, which is consistent with the actual situation.
This method for assessing the risk of rockburst breaks through the limitations of the traditional mining space research and establishes the relationship between the regional geological environment and rockbursts. This method provides a new tool for the evaluation and prediction of rockburst in new mines and new mining levels.

\section{Conclusions}

Whether dynamic disasters will occur in a mine depends on the regional geodynamic environment. Mining activities in areas of energy accumulation under the influence of regional geological dynamics can easily cause mine dynamic disasters, such as rockbursts.

A statistical analysis on some mines with rockbursts in China was performed. The effects of the impacts of geodynamic factors on rockbursts, including mining depth, tectonic stress, tectonic movements, and fault structure tectonic subsidence, were determined. An assessment method and an indicator system for the geodynamic environments for rockbursts were established.

The Tongxin coal mine in Shanxi province was taken as an example. The assessment method was applied to evaluate the risk for rockbursts, and the results were consistent with reality.

The assessment method provides a new method for the evaluation and prediction of rockbursts in new coal mines or new mining levels. 
TABLE 12

\begin{tabular}{lcccc}
\hline Evaluation grade & Negligible risk & Slight risk & Moderate risk & Serious risk \\
\hline Degree of membership & 0.3713 & 0.5851 & 0.2729 & 0.4150 \\
\hline
\end{tabular}

\section{Conflicts of Interest}

The authors declare no conflicts of interest.

\section{Authors' Contributions}

Zhijie Zhu analysed the data and established the risk assessment method for the rockbursts. Hongwei Zhang, Jun Han, and Youchang Lyu revised the manuscript and adjusted the data presentation. The authors all wrote the paper.

\section{Acknowledgments}

This work was financially supported by the National Key R\&D Program of China (Grant no. 2017YFC0804203) and the National Natural Science Foundation of China (51704148, 51674135, and 51774174).

\section{References}

[1] Y.-D. Jiang, Y.-S. Pan, F.-X. Jiang, L.-M. Dou, and Y. Ju, "State of the art review on mechanism and prevention of coal bumps in China," Journal of Coal Science \& Engineering (China), vol. 39, no. 2, pp. 205-213, 2014.

[2] W. Cai, L. Dou, G. Si, A. Cao, J. He, and S. Liu, "A principal component analysis/fuzzy comprehensive evaluation model for coal burst liability assessment," International Journal of Rock Mechanics and Mining Sciences, vol. 81, pp. 62-69, 2016.

[3] Z. Wen, X. Wang, Y. Tan, H. Zhang, W. Huang, and Q. Li, "A study of rockburst hazard evaluation method in coal mine," Shock and Vibration, vol. 2016, Article ID 8740868, 9 pages, 2016.

[4] S. W. Wang, D. B. Mao, T. T. Du, F. B. Chen, and M. H. Feng, "Rockburst hazard evaluation model based on seismic CT technology," Journal of China Coal Society, vol. 37, pp. 1-6, 2012.

[5] N. Hosseini, "Evaluation of the rockburst potential in longwall coal mining using passive seismic velocity tomography and image subtraction technique," Journal of Seismology, vol. 21, no. 5, pp. 1101-1110, 2017.

[6] W. Cai, L. Dou, A. Cao, S. Gong, and Z. Li, "Application of seismic velocity tomography in underground coal mines: a case study of Yima mining area, Henan, China," Journal of Applied Geophysics, vol. 109, pp. 140-149, 2014.

[7] A.-Y. Cao, L.-M. Dou, C.-B. Wang, X.-X. Yao, J.-Y. Dong, and Y. Gu, "Microseismic precursory characteristics of rock burst hazard in mining areas near a large residual coal pillar: a case study from xuzhuang coal mine, xuzhou, China," Rock Mechanics and Rock Engineering, vol. 49, no. 11, pp. 1-16, 2016.

[8] J. M. Alcott, P. K. Kaiser, and B. P. Simser, "Use of microseismic source parameters for rockburst hazard assessment," Pure and Applied Geophysics, vol. 152, no. 1, pp. 41-65, 1998.

[9] C.-P. Lu, G.-J. Liu, Y. Liu, N. Zhang, J.-H. Xue, and L. Zhang, "Microseismic multi-parameter characteristics of rockburst hazard induced by hard roof fall and high stress concentration,"
International Journal of Rock Mechanics and Mining Sciences, vol. 76, pp. 18-32, 2015.

[10] Y. X. Xia, L. J. Kang, Q. X. Qi et al., "Five indexes of microseismic and their application in rock burst forecastion," Journal of China Coal Society, vol. 35, pp. 2011-2016, 2010.

[11] C. W. Wang, F. X. Jiang, Q. G. Sun et al., "The forecasting method of rock-burst and the application based on overlying multistrata spatial structure theory," Journal of China Coal Society, vol. 34, pp. 150-155, 2009.

[12] J. F. Pan, S. W. Wang, S. H. Liu, and M. H. Feng, "Pre-evaluation of burst hazards based on concentrated static load detection," Chinese Journal of Geotechnical Engineering, vol. 36, pp. 12271234, 2014.

[13] F. X. Jiang, Y. Liu, M. H. Zhai et al., "Evaluation of rock burst hazard based on the classification of stress and surrounding rock," Chinese Journal of Rock Mechanics and Engineering, vol. 36, pp. 1041-1052, 2017.

[14] Z. W. Sun, J. Dai, C. M. Yang, and J. F. Yang, "lastic energy criterion of rock burst in roadway and coalface of mine," Journal of China Coal Society, vol. 32, pp. 794-798, 2007.

[15] L. M. Xu, Li. Qi; Pan, Y. S. Li, Z. H. Li, G. Z. Ma, and Xiao., "Study on forecasting rockburst of pipe torque method," Journal of Engineering Mechanics, vol. 31, pp. 251-256, 2014.

[16] Y. S. Pan and L. M. Xu, "Experimental investigation on temperature of drilling cuttings to predict rock burst," Chin. J. Geot. Eng, vol. 34, pp. 2228-2232, 2012.

[17] Y. S. Pan, Y. F. Zhao, and G. Z. Li, "Charge induced technique of rockburst prediction and its application," Chinese Journal of Rock Mechanics and Engineering, vol. 31, pp. 3988-3993, 2012.

[18] M. Cai, "Prediction and prevention of rockburst in metal mines A case study of Sanshandao gold mine," Journal of Rock Mechanics and Geotechnical Engineering, vol. 8, no. 2, pp. 204-211, 2016.

[19] C. P. Lu, L. M. Dou, N. Zhang, J. H. Xue, X. N. Wang, and H. Liu, "Microseismic frequency-spectrum evolutionary rule of rockburst triggered by roof fall," International Journal of Rock Mechanics and Mining, vol. 64, pp. 6-16, 2013.

[20] C. P. Lu, G. J. Liu, N. Zhang, T. B. Zhao, and Y. Liu, "Inversion of stress field evolution consisting of static and dynamic stresses by microseismic velocity tomography," International Journal of Rock Mechanics and Mining, vol. 87, pp. 8-22, 2016.

[21] C. P. Lu, Y. Liu, H. Y. Wang, and P. F. Liu, "Microseismic signals of double-layer hard and thick igneous strata separation and fracturing," International Journal of Coal Geology, vol. 160-161, Article ID 160161, pp. 28-41, 2016.

[22] H. W. Zhang, F. Zhu, J. Han, B. J. Huo, H. Rong, and G. S. Tang, "Geological dynamic conditions and forecast technology for rock bursts," Journal of China Coal Society, vol. 41, pp. 545551,2016

[23] H. W. Zhang, K. Du, H. Rong, and Y. W. Gao, "Tectonic stress condition of rock burst," Journal of Liaoning Technical University (Natural Science Edition), vol. 34, pp. 165-169, 2015.

[24] Y. Chen, H. Zhang, B. Yu, Z. Zhu, W. Wu, and Y. Li, "Study of Influence of Regional Geodynamic Background on Strata Behaviors in China's Tongxin Mine," Resource Geology, vol. 66, no. 1, pp. 1-11, 2015. 
[25] H. W. Zhang, "Geodynamic environment analysis and evaluation of mine dynamic disasters," in Proceedings of the First China-Russia High-level Forum on deep rock mining dynamics, Fuxin, China, 2011.

[26] P. Z. Zhang, Q. D. Deng, and Z. Q Zhang, "Active faults, earthquake hazards and associated geodynamic processes in continental China," Science China Chemistry, vol. 43, pp. 1607-1620, 2013.

[27] J. Han, B. Liang, H. W. Zhang et al., "Tectonic stress environment of coal and rock dynamic hazard in Kailuan mining area," Journal of China Coal Society, vol. 38, pp. 1154-1160, 2013.

[28] C. Mark and M. Gauna, "Evaluating the risk of coal bursts in underground coal mines," International Journal of Mining Science and Technology, vol. 26, no. 1, pp. 47-52, 2016.

[29] L. M. Dou and X. Q. He, Prevention theory and technology of rockburst, China University of Mining and Technology Press, Xuzhou, China, 2001.

[30] J. Han, H. W. Zhang, S. Li, and W. H. Song, "The characteristic of in situ stress in outburst area of China," Safety Science, vol. 50, no. 4, pp. 878-884, 2012.

[31] J. Han, L. Bin, and H. W. Zhang, "Tectonic stress environment of coal-rock dynamic hazard," in Proceedings of the 13 Coal Operators' Conference, Wollongong, Australia, 2013.

[32] Y. Li, G. Yang, S. Yang, and L. Guo, "Preliminary division of active block boundary in Chinese mainland based on recent vertical crustal movement," Acta Seismologica Sinica, vol. 14, pp. 11-16, 2001.

[33] H.-W. Zhang, F. Zhu, J. Han, B.-J. Huo, H. Rong, and G.-S. Tang, "Geological dynamic conditions and forecast technology for rock bursts," Journal of China Coal Society, vol. 41, no. 3, pp. 545-551, 2016.

[34] Z. L. Mu, L. M. Dou, X. H. Ni, and M. W. Zhang, "Research on the influence of roof strata on rock burst risk," J China Univ Mining Technol, vol. 39, pp. 40-44, 2010.

[35] P. Z. Zhang, Q. D. Deng, and Z. Q. Zhang, "Active faults, earthquake hazards and associated geodynamic processes in continental China," Scientia Sinica Terrae, vol. 43, pp. 1607-1620, 2013.

[36] T. L. Saaty, "Rank from comparisons and from ratings in the analytic hierarchy/network processes," European Journal of Operational Research, vol. 168, no. 2, pp. 557-570, 2006.

[37] H. Sun, S. Wang, and X. Hao, "An Improved Analytic Hierarchy Process Method for the evaluation of agricultural water management in irrigation districts of north China," Agricultural Water Management, vol. 179, pp. 324-337, 2016.

[38] L. S. Iliadis, "A decision support system applying an integrated fuzzy model for long-term forest fire risk estimation," Environmental Modeling and Software, vol. 20, no. 5, pp. 613-621, 2005. 


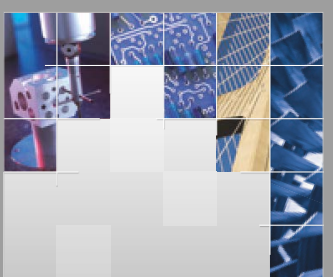

\section{Enfincering}
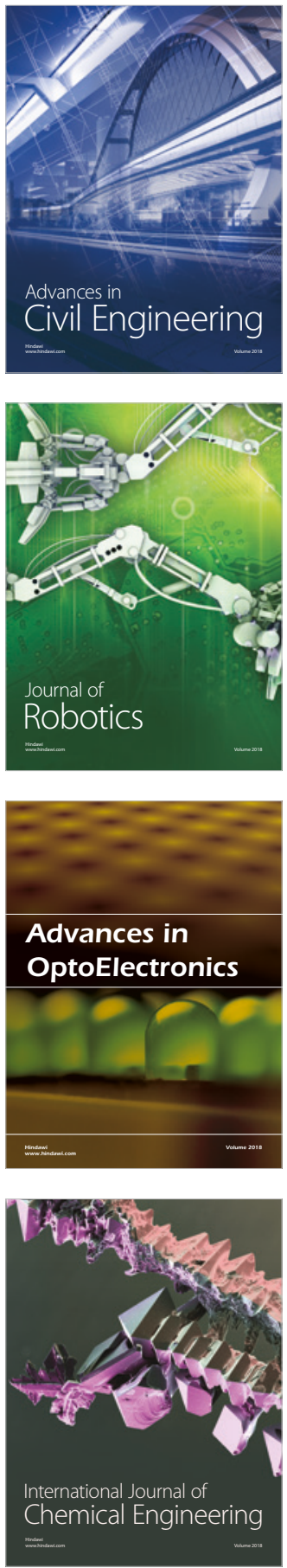

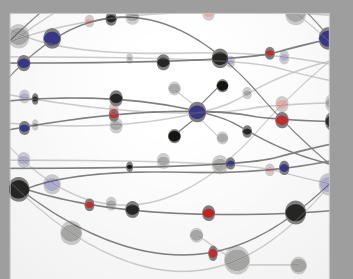

\section{Rotating \\ Machinery}

The Scientific World Journal

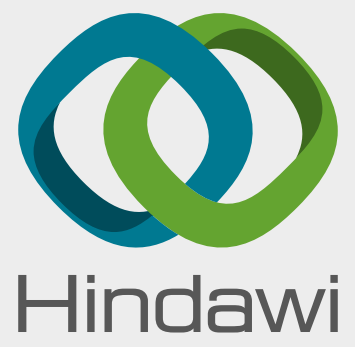

Submit your manuscripts at

www.hindawi.com
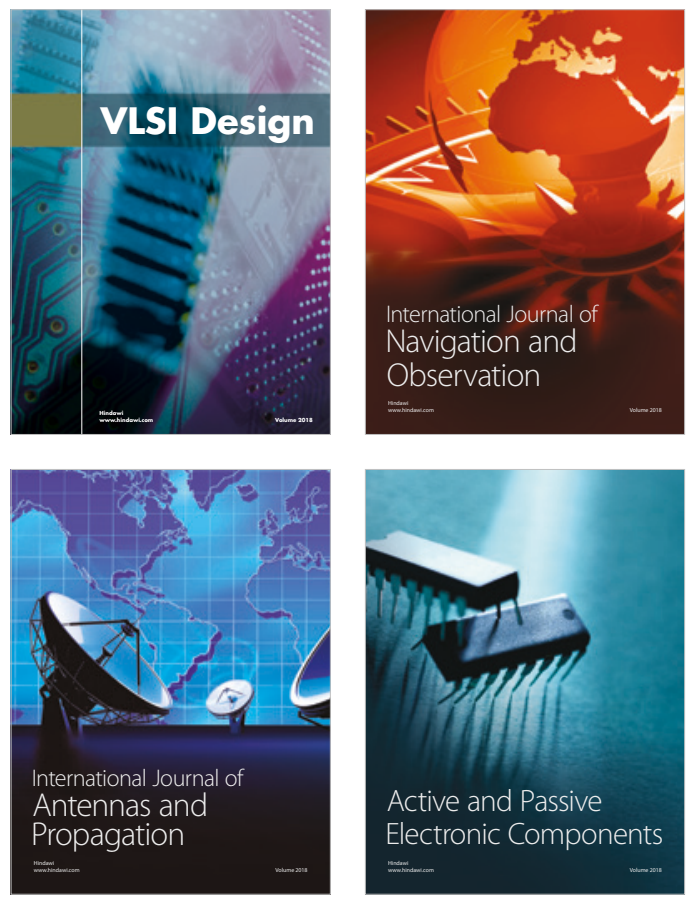
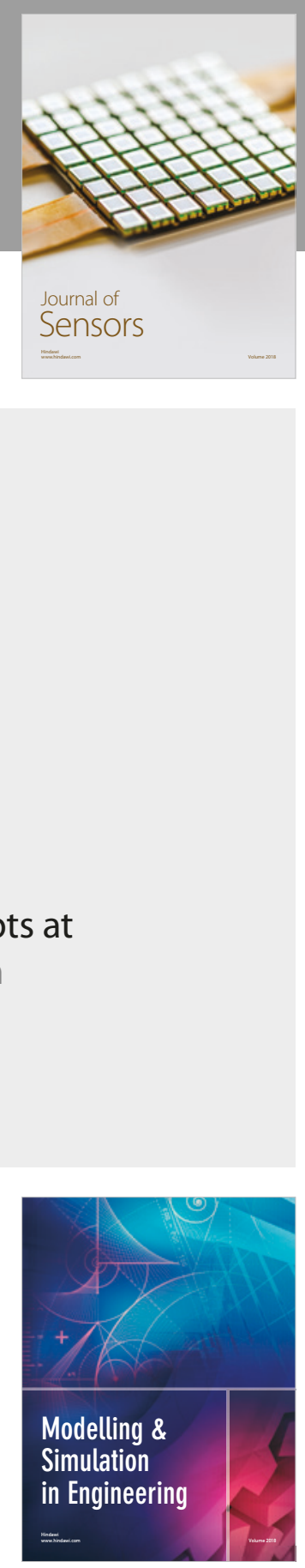

\section{Advances \\ Multimedia}
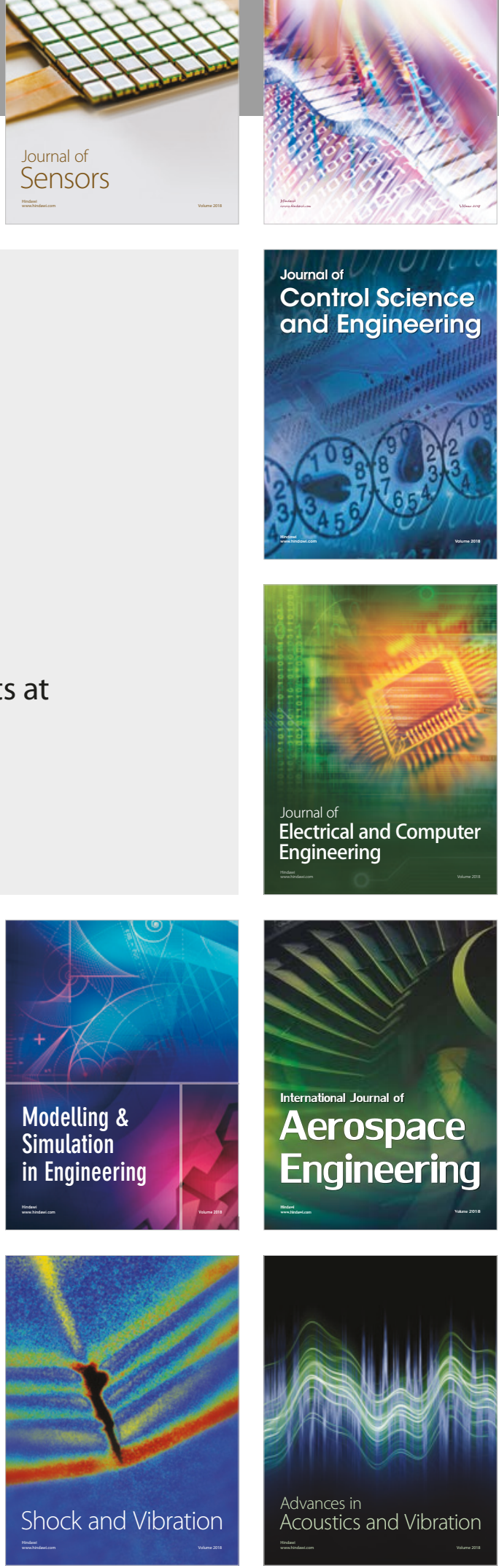